\title{
EFFECTS OF S-8527 (1, 1-BIS [4'-(1"'-CARBOXY-1"-METHYLPRO- POXY) PHENYL] CYCLOHEXANE), A NEW HYPOLIPIDEMIC COMPOUND, ON PLATELET AGGREGATION, ADHESIVE- NESS AND BLOOD COAGULATION IN RATS
}

\author{
Kotaro SUZUKI \\ Research Department, Pharmaceuticals Division, Takarazuka Research Laboratories, \\ Sumitomo Chemical Co Ltd., Takarazuka, Japan \\ Accepted April 30, 1975
}

\begin{abstract}
Effects of S-8527 (1,1-bis[4'-(1"-carboxy-1"-methylpropoxy) phenyl] cyclohexane) on platelet aggregation, adhesiveness and blood coagulation were examined in rats. In animals maintained on a semisynthctic diet containing sucrose $(62 \%)$ as the only carbohydrate source, platelet adhesiveness increased as compared with that in rats fed a normal chow pellet. Under these experimental conditions, oral dose of $\mathbf{S}-8527$ (30-300 mg/kg) for 14 days decreased platelet adhesiveness and ADP-induced platelet aggregation, but did not decrease collagen-induced platelet aggregation. S-8527 also showed a slight but significant increase of $\mathrm{R}$ value of thrombelastograph. In rats which were fed a normal chow pellet oral dose of S-8527 for 14 days did not significantly affect the several tests of platclet function and blood coagulation. These results suggest that S-8527 normalizes the platelet function in a hyper-adhesive state, but does not affect the platelet function in a normal state.
\end{abstract}

Hyperlipidemia is considered a major risk factor in the development of atherosclerosis $(1,2)$. Pharmacological agents that decrease plasma lipid concentration are currently being used in an attempt to prevent atherosclerosis and its complications (3-6). We have shown that the hypolipidemic effect of S-8527 (1,1-bis [4'-(1"'-carboxy-1"'-methylpropoxy) phenyl] cyclohexane) is about ten times more potent that that of elofibrate but the hepatomegalic effect of S-8527 is far less that that of clofibrate in rats $(7-10)$.

There is also an important relationship between intra-arterial thrombosis and atherosclerosis, not only because intra-arterial thrombosis is partly responsible for the mortality due to atherosclerosis (11), but also because it probably plays a primary role in etiology of the atherosclerosis process (12).

In the present study, the effects of $\mathrm{S}-8527$ on so called "thrombogenic parameters" (platelet aggregation, platelet adhessiveness, thrombelastography values, clotting times and fibrinogen levels) were studied in rats.

\section{MATERIALS AND METHODS}

\section{Treatment of animals}

Male Wistar rats weighing $200-250 \mathrm{~g}$ were fed a semisynthetic diet containing sucrose as the only carbohydrate source or a normal chow pellet diet (NIPPON CLEA, CE-2). The composition of the semisynthetic diet used was as follows: $62 \%$ sucrose, $18 \%$ casein, 
$5 \%$ lard, $8 \%$ cellulose powder, $5 \%$ salt mixture (U.S.P. XVII) and $2 \%$ vitamin mixture. S-8527 and clofibrate were suspended in an appropriate amount of $5 \%$ gum arabic solution, so that the daily dose would be $0.5 \mathrm{ml}$ per $100 \mathrm{~g}$ of body weight: it was given to the rats via stomach tube every a.m. for 14 days. Control groups were on an equal volume of the vehicle. Twenty-four hours after the last dose of S-8527 or clofibrate, the rats were anesthetized with ether. Blood was collected from the inferior vena cava into a polyethylene test tube containing 1 vol. of $3.8 \%$ citrate per 9 vol. of blood. Citrated whole blood samples from two rats were pooled to study the effects on platelet aggregation, thrombelastography values, clotting tests and plasma components.

\section{Assay of platelet aggregation}

This study was performed according to the method of Mills and Roterts (13). Platelet rich and platelet poor plasma were prepared by centrifuging citrated blood at $1,500 \mathrm{rpm}$ for $15 \mathrm{~min}$ and $3,000 \mathrm{rpm}$ for $20 \mathrm{~min}$, respectively, at room temperature. Plasma was transferred to the polyethylene tube at room temperature for immediate testing. An aggregometer (Bryston, Canada) was used. Samples of $0.5 \mathrm{ml}$ of platelet rich plasma were pipetted into the cuvette and warmed to $37^{\circ}$ stirring at $1,100 \mathrm{rpm}$ before adding a stimulus. After $5 \mathrm{~min}, 0.05 \mathrm{ml}$ of ADP or collagen in Tris-saline (13) was added to the cuvette (final ADl' concentration in platelet rich plasma was $2.5 \mu \mathrm{g} / \mathrm{ml}$ or $10 \mu \mathrm{g} / \mathrm{ml}$, and final collagen concentration was $100, " \mathrm{~g} / \mathrm{ml}$ ). Suspension of collagen was prepared using a glass homogenizcr. The degree of aggregation was measured after addition of a stimulus by the maximum change in optical density of platelet rich plasma when the sensitivity was adjusted to 0 in optical density (100\% transmittance) with platelet poor plasma.

Assay of thrombelastography value

This was carried out as described by Hartert (14). In a polyethylene tube, $0.6 \mathrm{ml}$ of the citrated whole blood was pipetted with the aid of a polyethylene pipette and $0.4 \mathrm{ml}$ of 0.25 $\mathrm{M} \mathrm{CaCl}_{2}$ solution was added. Immediately after mixing the blood samples, $0.36 \mathrm{ml}$ of the mixture was put into the cell which had been placed in the thrombelastograph.

\section{Determination of clotting times}

Assay of rccalcification time, partial thromboplastin time, prothrombin time and thrombin time was carried out using the citrated platelet poor plasma (15).

\section{Assay of platelet adhesiveness}

Platclet adhesiveness to glass beads was tested by the Salzman method (16). A piece of polyvinyl tube $(2.8 \times 120 \mathrm{~mm})$ which filled with glass beads $(0.6-0.7 \mathrm{~mm}$, diameter) was used. Blood was collected from the inferior vena cava of the rats, which had been anesthesized with ether $24 \mathrm{hr}$ after the last dosing, through the glass tube into polyethylene syringe containing a small amount of EDTA ( $2 \mathrm{Na})$. The rate of blood flow through the column was standarized to $1 \mathrm{ml}$ per $36 \mathrm{sec}$ using a motor-driven syringe. The difference in the platelet count before and after the passage of the column represents the number of adhesive platelets and this is expressed as a percentage of pre-filter count. Platelet count was done on a Coulter Thrombocounter (17). 


\section{Assay of fibrinogen and plasma lipids}

Fibrinogen levels were determined as total thrombin-precipitable protein by the method of Lowry et al. (18) after syneresis of the clots on filter paper. Plasma triglycerides and cholesterol were assayed using a Technicon Autoanalyzer (19).

\section{Chemicals}

S-8527 was synthesized in this laboratory. Clofibrate (ethyl p-chlorophenoxyisobutyrate) was obtained from Imperial Chemical Industries Ltd. in England.

\section{RESULTS}

In the first experiment, the rats were maintained on a semisynthetic diet containing sucrose $(62 \%)$ as the only carbohydrate source. Table 1 shows the effects on the several tests of platelet function. After the feeding of a semisynthetic diet for 14 days, platelet adhesiveness increased almost double in comparison with that in the rats on a normal chow pellet diet. Platelet aggregation and platelet count showed no significant changes beween the rats on a semisynthetic diet and those on a normal chow pellet. In rats given a daily oral dose of S-8527, platelet adhesiveness decreased by about $23 \%$ at a dose of $30 \mathrm{mg} /$ $\mathrm{kg}$ and $30 \%$ at a dose of $300 \mathrm{mg} / \mathrm{kg}$, respectively. ADP-induced platelet aggregation decreased by about $2550 \%$ at a dose of $300 \mathrm{mg} / \mathrm{kg}$, but collagen-induced platelet aggregation was not significantly altered by $\mathrm{S}-8527$. On the other hand, clofibrate $(300 \mathrm{mg} / \mathrm{kg})$ decreased collagen-induced platelet aggregation by about $28 \%$, but did not significantly alter ADPinduced platelet aggregation and platelet adhesiveness. No significant alteration in the platelet count between control and S-8527 or clofibrate treated groups was found. Table

TABLE 1. Effects of S-8527 and clofibrate on several tests of platelet function in rats fed a semisynthetic diet containing sucrose as the only carbohydrate source

\begin{tabular}{|c|c|c|c|c|c|}
\hline \multirow{4}{*}{ Treatment } & \multicolumn{3}{|c|}{ Platelet aggregation } & \multirow{3}{*}{$\begin{array}{c}\text { Platelet } \\
\text { adhesiveness } \\
\text { Salzman tube } \\
\text { test }\end{array}$} & \multirow{3}{*}{$\begin{array}{l}\text { Platelet count } \\
\times 10^{4} / \mathrm{mm}^{3}\end{array}$} \\
\hline & \multicolumn{2}{|c|}{ ADP } & \multirow{2}{*}{$\begin{array}{c}\text { Collagen } \\
100, \text { g:ml }\end{array}$} & & \\
\hline & $10,: \mathrm{g} / \mathrm{ml}$ & $2.5: \mathrm{g} / \mathrm{ml}$ & & & \\
\hline & \multicolumn{3}{|c|}{$\begin{array}{c}\text { maximum change of optical density } \\
\left(\text { OD. } \times 10^{2}\right)\end{array}$} & $\%$ & \\
\hline Control & $\begin{array}{r}59.5 \\
\therefore \quad 3.2(7)\end{array}$ & $\begin{array}{r}41.3 \\
+4.3(5)\end{array}$ & $\begin{array}{l}57.4 \\
+5.7(6)\end{array}$ & $\begin{array}{r}61.7 \\
5.6(9)\end{array}$ & $\begin{array}{l}40.2 \\
1.1 .8(10)\end{array}$ \\
\hline $\begin{array}{l}\mathrm{S}-8527 \\
\quad 30 \mathrm{mg} / \mathrm{kg}\end{array}$ & $\begin{array}{l}55.5 \\
5.4(7)\end{array}$ & $\begin{array}{l}38.2 \\
\vdots 7.6(7)\end{array}$ & $\begin{array}{l}46.3 \\
\pm 4.9(6)\end{array}$ & $\begin{array}{r}47.1 \\
.10 .1(10)\end{array}$ & $\begin{array}{l}40.4 \\
\leq 1.2(10)\end{array}$ \\
\hline $\begin{array}{r}\mathrm{S}-8527 \\
300 \mathrm{mg} / \mathrm{kg}\end{array}$ & $\begin{array}{l}44.0^{*} \\
+5.7(7)\end{array}$ & $\begin{array}{l}21.4^{*} \\
\therefore-5.0(7)\end{array}$ & $\begin{aligned} & 43.4 \\
\pm & 8.9(6)\end{aligned}$ & $\begin{aligned} & 44.2 * \\
&+\quad 5.8(9)\end{aligned}$ & $\begin{array}{l}47.2 \\
\pm 4.2(10)\end{array}$ \\
\hline $\begin{array}{l}\text { Clofibrate } \\
\quad 300 \mathrm{mg} / \mathrm{kg}\end{array}$ & $\begin{array}{r}59.4 \\
- \pm 2.6(6)\end{array}$ & $\begin{array}{l}42.9 \\
\pm 3.3(6)\end{array}$ & $\begin{array}{l}41.3^{*} \\
=2.3(6)\end{array}$ & $\begin{array}{r}51.9 \\
\pm \quad 7.2(8)\end{array}$ & $\begin{aligned} & 45.2 \\
\pm & -2.8(8)\end{aligned}$ \\
\hline Normal diet & $\begin{array}{r}60.5 \\
-1.6(6)\end{array}$ & $\begin{array}{l}44.1 \\
=-1.3(6)\end{array}$ & $\begin{array}{r}52.6 \\
\pm \\
+5.6(6)\end{array}$ & $\begin{aligned} & 34.6^{* *} \\
&-\quad 3.2(9)\end{aligned}$ & $\begin{aligned} & 39.4 \\
\doteq & 2.9(10)\end{aligned}$ \\
\hline
\end{tabular}

For studying the effects on platelet aggregation, blood samples from two fats were pooled. Each value represents the means S.E. for the number of determinations shown in parentheses. In the study of platelet adhesiveness and platelet count, each value represents the mean - S.E. for the number of animals indicated in parentheses.

* Significantly different from control $(\mathrm{P}<0.05)$

** Significantly different from control $(\mathrm{P}<0.01)$. 
TABLF 2. Effects of S-8527 and clofibrate on thrombelastography values in rats fed a semisynthetic diet containing sucrose as the only carbohydrate source

Treatment

Thrombelastography values

\begin{tabular}{|c|c|c|c|c|c|}
\hline \multirow{2}{*}{\multicolumn{2}{|c|}{ Trealment }} & \multirow[b]{2}{*}{$\mathrm{R}(\min )$} & \multirow[b]{2}{*}{$\mathrm{K}(\mathrm{min})$} & \multirow[b]{2}{*}{$\mathrm{R}: \mathrm{K}(\min )$} & \multirow[b]{2}{*}{$\mathrm{MA}(\mathrm{mm})$} \\
\hline & & & & & \\
\hline Control & (7) & $1.8: 0.1$ & $1.9 \pm 0.4$ & $3.7 \leq 0.5$ & $59.2 \div 2.7$ \\
\hline $\mathrm{S}-852730 \mathrm{mg} / \mathrm{kg}$ & (7) & $2.5-0.2 * *$ & $2.2 \pm 0.3$ & $4.6+0.2$ & $56.0 \pm 2.3$ \\
\hline $\mathrm{S}-8527300 \mathrm{mg} / \mathrm{kg}$ & (7) & $2.6=0.1 * * *$ & $2.2 \div 0.3$ & $4.9-\ldots .2 *$ & $54.1+2.1$ \\
\hline Clofibrate $300 \mathrm{mg} / \mathrm{kg}$ & (5) & $2.2-0.1$ & $2.5 \pm 0.3$ & $4.9: 0.2$ & $55.0 \pm 0.6$ \\
\hline Normal diet & (5) & $2.0+0.1$ & $2.1: 0.3$ & $4.1: 0.4$ & $59.0+1.3$ \\
\hline
\end{tabular}

Blood samples from two rats were pooled. Each value represents the mean \pm S.E.

for the number of determinations shown in parentheses.

$\mathrm{R}$, reaction time. $\mathrm{K}$, clot-formation time. MA, maximum amplitude.

* Significantly different from control $(P<0.05)$.

* Significantly different from control $(P<0.01)$.

*** Significantly different from control $(\mathbf{P}<0.001)$.

2 shows the effects on the thrombelastography values in rats on a semisynthetic diet. $R$ and $K$ values tended to decrease in comparison with rats on a normal chow diet. S-8527 showed a slight increase of $R$ and $K$ values. Increase of $R$ value was statistically significant. Clofibrate showed similar results. In addition, both compounds somewhat decreased the MA value but there wcre no significant differences. Table 3 shows the effects on clotting tests, fibrinogen levels and plasma lipid levels in rats on a semisynthetic diet. In S-8527 and clofibrate treated rats, there were increases in recalcification time and a decrease in fibrinogen Icvels, but the difference did not reach statistical significance.

TABIE 3. Ellects of S-8527 and clofibrate on clotting tests, fibrinogen and plasma lipid levels in rats fed a semisynthetic diet containg sucrose as the only carbohydrate source

\begin{tabular}{|c|c|c|c|c|c|}
\hline Treatment & Control & $\begin{array}{l}\mathrm{S}-8527 \\
30 \mathrm{mg} \mathrm{kg}\end{array}$ & $\begin{array}{c}\mathrm{S}-8527 \\
300 \mathrm{mg} ! \mathrm{kg}\end{array}$ & $\begin{array}{l}\text { Clofibrate } \\
300 \mathrm{mg} / \mathrm{kg}\end{array}$ & Normal diet \\
\hline $\begin{array}{c}\text { Recalcification time } \\
\text { (sec) }\end{array}$ & $58.5 \cdot 2.5$ & $\frac{63.0}{(7)} 4.8$ & $68.6 \cdot 6.2$ & $\begin{array}{c}61.4-4.2 \\
(6)\end{array}$ & $64.5+2.8$ \\
\hline $\begin{array}{c}\text { Partial thromboplastin } \\
\text { time (sec) }\end{array}$ & $\begin{array}{c}30.5-1.1 \\
(7)\end{array}$ & $\begin{array}{c}32.0-1.6 \\
(7)\end{array}$ & $\begin{array}{c}30.1-1.0 \\
(5)\end{array}$ & $\begin{array}{l}29.9 ! 0.6 \\
(6)\end{array}$ & $29.7 \div 1.8$ \\
\hline $\begin{array}{l}\text { Prothrombin time } \\
\qquad(\mathrm{sec})\end{array}$ & $\begin{array}{c}14.8 \div 0.3 \\
(6)\end{array}$ & $\begin{array}{c}16.3 \ldots 0.5 * \\
(7)\end{array}$ & $\begin{array}{c}15.9 \div 0.7 \\
(7)\end{array}$ & ${ }_{(6)}^{15.1 !} 0.4$ & 14.4 .10 .2 \\
\hline $\begin{array}{l}\text { Thrombin time } \\
\text { (sec) }\end{array}$ & $13.7 \div 0.6$ & $\begin{array}{c}15.4: 0.9 \\
(7)\end{array}$ & $14 . \underset{(7)}{2-:} 0.5$ & $\begin{array}{c}12.8-1.2 \\
(6)\end{array}$ & $14 . \underset{(6)}{4 \perp} 0.5$ \\
\hline Fibrinogen $(\mathrm{mg} 100 \mathrm{ml})$ & $223.2-24.2$ & $\begin{array}{c}216.4 \\
(6)\end{array}$ & $205.3+48.2$ & $158.3 \ldots 22.3$ & $205.0 \div 11.9$ \\
\hline $\begin{array}{c}\text { Plasma triglycerides } \\
(\mathrm{mg} 100 \mathrm{ml})\end{array}$ & $\begin{array}{c}103.7 \div 8.5 \\
(6)\end{array}$ & $46.9+4.9^{* * *}$ & $\begin{array}{c}35.9+4.3^{* * *} \\
(4)\end{array}$ & $60.1-8.5 * *$ & $131.2-5.3$ \\
\hline $\begin{array}{l}\text { Plasma cholesterol } \\
(\mathrm{mg}: 100 \mathrm{ml})\end{array}$ & $76.1-3.1$ & $47.5=2.0^{* * *}$ & $* 36.5-4.8^{* * *}$ & ${ }_{(5)}^{49.8 \ldots 1.3^{* * *}}$ & $*{ }_{(5)}^{56.2} 2^{*} .1^{* * *}$ \\
\hline
\end{tabular}

Blood samples from two rats were pooled. Each value represents the mean..+ S.E. for the number of determinations shown in parentheses.

* Significantly different from control $(\mathrm{P}<0.05)$.

** Significantly diferent from control $(\mathrm{P}<0.01)$.

$* * *$ Significantly different from control $(P .001)$. 
TABLE 4. Effects of S-8527 and clofibrate on several tests of platelet function in rats fed a normal chow diet

\begin{tabular}{|c|c|c|c|}
\hline \multirow{3}{*}{ Treatment } & Platelet aggregation & \multirow{3}{*}{$\begin{array}{l}\text { Platelet adhesiveness } \\
\text { Salzman tube test }\end{array}$} & Platelet count \\
\hline & ADP $10 \mu \mathrm{g} / \mathrm{ml}$ & & \multirow{2}{*}{$\therefore 10^{4} / \mathrm{mm}^{3}$} \\
\hline & $\begin{array}{l}\text { maximum change of optical } \\
\text { density }\left(\Lambda \text { O.D. } \times 10^{2}\right)\end{array}$ & & \\
\hline Control & $51.8=8.2(7)$ & $49.4 \pm 7.4(9)$ & $39.7-1.4(9)$ \\
\hline $\mathrm{S}-852730 \mathrm{mg} / \mathrm{kg}$ & $55.2 \cdots 9.2(7)$ & $46.8-18.0(10)$ & $40.6=2.5(10)$ \\
\hline $\mathrm{S}-8527300 \mathrm{mg} / \mathrm{kg}$ & $52.9 \approx 2.7(9)$ & $49.6: 6.5(9)$ & $52.9=8.7(7)^{* * *}$ \\
\hline Clofibrate $300 \mathrm{mg} / \mathrm{kg}$ & $49.2 \pm 10.4(7)$ & $54.7 \pm 8.5(9)$ & $42.2 \div 3.6(9)$ \\
\hline
\end{tabular}

For studying the effects on platelet aggregation, blood samples from two rats were pooled. Each value represents the mean =- S.E. for the number of determinations shown in parentheses. In the study platelet adhesiveness and platelet count, cach value represents the mean : S.E. for the number of animals shown in parentheses.

* Significantly different from control (P<0.01).

TARLE 5. Effects of S-8527 and clofibrate on thrombelastography values in rats fed a normal chow diet

\begin{tabular}{lccccc}
\hline \multicolumn{1}{c}{ Treatment } & \multicolumn{5}{c}{ Thrombelastography values } \\
& & $\mathrm{R}(\mathrm{min})$ & $\mathrm{K}(\mathrm{min})$ & $\mathrm{R}-\mathrm{K}(\mathrm{min})$ & $\mathrm{MA}(\mathrm{mm})$ \\
\hline Control & $(7)$ & $1.9 \pm 0.2$ & $2.1 \pm 0.3$ & $4.0 \pm 0.4$ & $55.3 \pm 2.1$ \\
S-8527 $30 \mathrm{mg} / \mathrm{kg}$ & $(7)$ & $2.2 \perp 0.2$ & $1.8 \perp 0.3$ & $4.1 \pm 0.3$ & $58.3 \pm 2.2$ \\
S-8527 300 $\mathrm{mg} / \mathrm{kg}$ & $(7)$ & $2.3 \pm 0.2$ & $2.4+0.5$ & $4.6+0.5$ & $55.9+2.2$ \\
Clofibrate $300 \mathrm{mg} / \mathrm{kg}$ & $(7)$ & $2.2 \pm 0.2$ & $2.9 \pm 0.2^{* *}$ & $5.1+0.3^{*}$ & $51.3 \div 3.3$ \\
\hline
\end{tabular}

Blood samples from two rats were each pooled. Each value represents the mean

- S.E. for the number of determinations shown in parentheses.

$\mathrm{R}$, reaction time. $\mathrm{K}$, clot-formation time. $\mathrm{MA}$, maximum amplitudc.

* Significantly different from control $(\mathrm{P}<0.05)$.

* Significantly different from control $(\mathrm{P}<0.01)$.

TABLE 6. Effects of S-8527 and clofibrate on clotting tests, fibrinogen and plasma lipid levels in rats fed a normal chow dict

\begin{tabular}{|c|c|c|c|c|}
\hline Treatment & Control & $\begin{array}{l}\mathrm{S}-8527 \\
30 \mathrm{mg} / \mathrm{kg}\end{array}$ & $\begin{array}{c}\mathrm{S}-8527 \\
300 \mathrm{mg} / \mathrm{kg}\end{array}$ & $\begin{array}{l}\text { Clofibrate } \\
300 \mathrm{mg} / \mathrm{kg}\end{array}$ \\
\hline Recalcification time (sec) & $\underset{(7)}{60.1-1.7}$ & $60.6: 3.5$ & $65.7+3.7$ & $59.1 \div 3.1$ \\
\hline $\begin{array}{l}\text { Partial thromboplastin time } \\
\qquad(\mathrm{sec})\end{array}$ & $\begin{array}{c}29.8-0.8 \\
\text { (7) }\end{array}$ & $28.9 \div 1.2$ & $26.8 \div 0.9$ & $\begin{array}{c}28.6-0.8 \\
(7)\end{array}$ \\
\hline Prothrombin time (sec) & $14.5 \underset{(4)}{0.1}$ & $15.3 \frac{4}{(4)} 3.6$ & $14.8 \div 0.5$ & $14.6+0.2$ \\
\hline Thrombin time (sec) & $12.8 \div 0.6$ & $12.2-(7) 0.2$ & $12.3 \frac{1}{(7)} 0.2$ & 11.6 .10 .3 \\
\hline Fibrinogen $(\mathrm{mg} / 100 \mathrm{ml})$ & 196.7 (7) 11.9 & $195.4+14.2$ & $159.5+6.4^{*}$ & $164.5+19.6$ \\
\hline $\begin{array}{l}\text { Plasma triglycerides } \\
\text { (mg/100 ml) }\end{array}$ & $119.6-7.3$ & $60.3 \frac{\overline{\overline{(6)}}}{\left(6.0^{* * * *}\right.}$ & $41.8+3.0^{* * * *}$ & $60.8 \div(7) 56^{* * *}$ \\
\hline $\begin{array}{l}\text { Plasma cholesterol } \\
\text { (mg/100 ml) }\end{array}$ & $55.1 \frac{1}{(7)} 2.1$ & $\begin{array}{c}40.4+3.5^{* *} \\
(6)\end{array}$ & $37.7 \frac{-2.7^{* * *}}{(7)}$ & $44.2 \div 3.9^{*}$ \\
\hline
\end{tabular}

Blood samples from two rats were poolcd. Each value represents the mean $\mathbf{E}$ S.E.

for the number of detcrminations shown in parentheses.

* Significantly different from control $(\mathrm{P}<0.05)$.

** Significantly different from control $(P<0.01)$.

*** Significantly different from control $(P<0.001)$. 
S-8527 lowered plasma lipids more effectively than clofibrate as previously reported $(7,8)$.

In the second experiment, the rats were maintained on a normal chow pellet diet. S8527 and clofibrate did not show significant effects in the several tests of platelet function (Table 4), thrombelastography values (Table 5) and clotting tests (Table 6) but did decrease fibrinogen levels (Table 6).

\section{DISCUSSION}

In rats on a semisynthetic diet containing sucrose as the only carbohydrate source, platelet adhesiveness and plasma cholesterol increased as compared with those in rats on a normal chow diet. There were also tendencies to an incrcase of fibrinogen levels, and decreases of $R$ value and recalcification time. These results indicate that the animals fed a semisynthetic diet containing sucrose as the only carbohydrate source are in a hyperadhesive, a hypercoagulable and a hyperlipidemic state. Dictary sucrose has been shown to have a influence on serum lipids in man $(20,21)$ and animals $(22,23)$. It was also reported that dietary sucrose increased platelet adhesiveness in man (24). These effects were confirmed in the present study. Under these experimental conditions, an oral dose of S-8527 for 14 days decreased the platelet adhesiveness and platelet aggregation, and increased the $\mathrm{R}$ value. But when S-8527 was given to rats fed a normal diet, these effects of S-8527 were absent, which suggests that S-8527 may not affect the platelet function and blood coagulability in a normal state but in a hyperadhesive and a hypercoagulable state, S-8527 may normalize the platelet function and blood coagulability.

S-8527 lowered plasma lipids in both the rats fed a semisynthetic diet and those fed a normal diet. However, S-8527 decreased the platelet function in the rats fed a semisynthetic diet containing sucrose as the only carbohydrate source. These results suggest that the effects of S-8527 in platelet function are independent of its effects on lipid levels.

It is generally acceptable that endogenous fatty acid synthesis is increased and the composition of the fatty acid is altered by feeding sucrose (20-24). The decrease in unsaturated fatty acid levels and accumulation of saturated fatty acid are observed. Nordöy (25) and Day et al. (26) reported that saturated fatty acids increased platelet adhesiveness and promoted thrombosis. A hyperadhesive and hypercoagulable state in rats fed a semisynthetic dict containing sucrose as the only carbohydrate source may be the results of altered tissue or plasma lipid properties. S-8527 was reported to decrease the endogenous triglyceride synthesis (9). Therefore, it is possible that accumulation of saturated fatty acid is decreased by S-8527, and a hyperadhesive and hypercoagulable state is returned to a normal one.

The action of clofibrate on lipid functions has been extensively confirmed by a number of clinical and experimental studies (27). Reduced platelet adhesiveness and platelet aggregation have been observed in several series in the course of treatment with clofibrate in man, although such findings have not always been confirmed (11). In the present stlldies, clofibrate decreased collagen-induced platelet aggregation but did not affect the other tests of platelet function and blood coagulation. 
Aggregability and adhesiveness of platelets are increased in certain diseases including atherosclerosis (28). Other studies suggested that platelet suppressing drugs may exert favorable effects regarding mortality from vascular diseases $(11,29)$. S-8528 may be applicable for the treatment of patients with a hypercoagulable, hyperadhesive and hyperaggregable picture in platelet analysis.

Acknowledgements: The author wishes to thank Drs. S. Yamaoka, K. Toki, H. Nakatani and $\mathrm{S}$. Aono for their pertinent advice and encouragement during this study.

\section{REFERENCES}

1) Dawier, T.R., Kannel, W.B., Revotskie, N. and Kagan, A.: Proc. R. Soc, Med. 55, 265 (1962)

2) At.BRINk, M.J.: Arch. Intern. Med. 109, 345 (1962)

3) Dewar, A.H.: Brit. Med. J. 4, 767 (1971)

4) Oliver, M.F.: Brit. Med. J. 4, 775 (1971)

5) Krasno, L.R. and Kidera, G.J.: $J$. Am. Med. Assoc. 219, 845 (1972)

6) KritCheVSKY, D.: Lipid 9, 97 (1974)

7) Toki, K., Nakamura, Y., Agatslma, K., Nakatan, H. and Aono, S.: Atheroselerosis 18, 101 (1973)

8) Suzuki, K., Aono, S. And Nakatani, H.: Japan. J. Pharmacol. 24, 407 (1974)

9) Suzukı, K.: Biochem. Pharmacol. 24, 1203 (1975)

10) Suzeki, K.: Biochem. Pharmacol. (in press)

11) Hampion, J.: Am. J. Cardiol. 27, 659 (1971)

12) Duguid, J.B.: J. Path. Bact. 60, 57 (1948)

13) Mills, D.C.B. And Roberts, G.C.K.: J. Physiol. 193, 443 (1967)

14) Hartert, H.: Klin. Wscher. 26, 577 (1948)

15) Bellfer, F.K. Ant Graff, H.: Thrombosis and Bleeding Disorders, Edited by Bang, N.U., Beller, F.K. Deutsch, E. ANd Mammen, E.F., p. 65, Academic Press, New York (1971)

16) Salzman, E.W.: J. Lab. clit. Med. 62, 724 (1963)

17) Bull, B.S. Schieiderman, M.A. and Brecher, G.: Am. J. Clin. Path. 44, 678 (1965)

18) Lowry, O.H., Rosebrovgh, N.J., FarR, A.L. and Randall, R.J.: J. biol. Chem. 193, 265 (1951)

19) Technicon Laboratory Method, N-24ᄉ and N-78

20) KLO, P.T. and Bassett, D.R.: Anm. Intern. Med. 62, 1199 (1965)

21) Kaufman, N.A., Poznayski, R., Blondhem, S.H. and Stein, Y.: Am. J. Clim. Nutr. 18, 261 (1966)

22) Portman, O.W., Lawry, E.Y. and BrLno, D. : Proc. Soc. exp. Biol. Med. 91,321 (1956)

23) Cohin, A.M. and Teitelbaum, A.: Life Sci. 7, 23 (1968)

24) Matsld , T.: Japan. J. Clin. Path. 21, 886 (1973)

25) Nordöy, A.: Thromb. Diath. Haemorrh. 13, 543 (1965)

26) Day, H.J., Ffwell, W. and Solonl, L.A.: Am. J. med. Sci. 253, 83 (1967)

27) Havel, R.J. and Kank, J.P.: Ann. Rer. Pharmacol. 13, 287 (1973)

28) Carvalho, A.G.A., Colmay, R.W. Avi Lles, R.S.: New. Lmgl. J. Med. 290, 434 (1974)

29) Mustard, J.F. and Packham, M.A.: Biochem. Pharmacol. 22, 3151 (1973) 